Article

\title{
Effect of Y Modified Ceria Support in Mono and Bimetallic Pd-Au Catalysts for Complete Benzene Oxidation
}

\author{
Lyuba Ilieva ${ }^{1}$, Anna Maria Venezia ${ }^{2, *(1)}$, Petya Petrova ${ }^{1}$, Giuseppe Pantaleo ${ }^{2}$ (D), \\ Leonarda Francesca Liotta ${ }^{2}\left(\mathbb{B}^{\circ}\right.$, Rodolfo Zanella $^{3}{ }^{(0)}$, Zbigniew Kaszkur ${ }^{4}$ (i) and \\ Tatyana Tabakova ${ }^{1, *}$ \\ 1 Institute of Catalysis, Bulgarian Academy of Sciences, 1113 Sofia, Bulgaria; luilieva@ic.bas.bg (L.I.); \\ inj_petrova@abv.bg (P.P.) \\ 2 Istituto per lo Studio dei Materiali Nanostrutturati, CNR, 90146 Palermo, Italy; \\ pantaleo@pa.ismn.cnr.it (G.P.); leonarda.liotta@ismn.cnr.it (L.F.L.) \\ 3 Instituto de Ciencias Aplicadas y Tecnología, Universidad Nacional Autónoma de México, \\ Circuito Exterior S/N, Ciudad Universitaria, C.P. 04510 Mexico City, Mexico; \\ rodolfo.zanella@ccadet.unam.mx \\ 4 Institute of Physical Chemistry, Polish Academy of Sciences, 01-224 Warsaw, Poland; zkaszkur@ichf.edu.pl \\ * Correspondence: annamaria.venezia@ismn.cnr.it (A.M.V.); tabakova@ic.bas.bg (T.T.)
}

Received: 21 June 2018; Accepted: 11 July 2018; Published: 16 July 2018

\begin{abstract}
Mono metallic and bimetallic Pd (1 wt. \%)-Au (3 wt. \%) catalysts were prepared using two ceria supports doped with $1 \mathrm{wt}$. \% $\mathrm{Y}_{2} \mathrm{O}_{3}$. Yttrium was added by impregnation or co-precipitation. The catalyst synthesis was carried out by deposition-precipitation method, with sequential deposition-precipitation of palladium over previously loaded gold in the case of the bimetallic samples. The obtained materials, characterized by X-ray powder diffraction (XRD), High resolution transmission electron microscopy (HRTEM), X-ray photoelectron spectroscopy (XPS), and temperature programmed reduction (TPR) techniques, were tested in the complete benzene oxidation (CBO). The results of the characterization analyses and the catalytic performance pointed to a close relationship between structural, redox, and catalytic properties of mono and bimetallic catalysts. Among the monometallic systems, Pd catalysts were more active as compared to the corresponding Au catalysts. The bimetallic systems exhibited the best combustion activity. In particular, over Pd-Au supported on Y-impregnated ceria, 100\% of benzene conversion towards total oxidation at the temperature of $150{ }^{\circ} \mathrm{C}$ was obtained. Comparison of surface sensitive XPS results of fresh and spent catalysts ascertained the redox character of the reaction.
\end{abstract}

Keywords: Au; Pd and Pd-Au catalysts; Y-doped ceria; complete benzene oxidation

\section{Introduction}

Volatile organic compounds (VOCs) are a major environmental hazard, being dangerous for human health because of their toxic nature as well as being ozone and smog precursors. Complete catalytic oxidation, leading to $\mathrm{CO}_{2}$ and water, is one of the most effective and economically feasible techniques for VOCs removal. As compared to thermal oxidation, catalytic combustion occurs at much lower temperature $\left(250-500{ }^{\circ} \mathrm{C}\right)$, allowing energy cost savings [1]. Due to the large variety of VOC molecules, the design of an appropriate catalyst with characteristics of high efficiency, selectivity and stability is rather crucial. The noble metals, as compared to transition metal oxides, are active at lower temperatures [2,3]. However, if not properly supported they may easily sinter and 
deactivate. By playing with several parameters, such as method of synthesis, particle sizes, and support morphology, it is possible to improve their catalytic performance [4,5].

The catalytic behavior of gold and palladium catalysts supported on different oxides have been investigated in the complete benzene oxidation (CBO) $[4,6,7]$. Several studies have indeed confirmed the suitability of supported gold nanoparticles, as catalysts for $\mathrm{CBO}$ reaction [8-12]. The combination of palladium and gold, supported on different carriers, from silicon nanowires, $\mathrm{CeO}_{2}$, and $\mathrm{TiO}_{2}$ has been also considered in several environmentally important reactions [13-23]. According to literature, the sequence of the two- metal loading has a strong impact on the catalyst activity and stability [19-24]. As recently reported, the deposition of palladium on a Fe doped $\mathrm{CeO}_{2}$ supported gold catalyst allowed high CBO performance to be obtained [25]. Cerium (IV) oxide, in virtue of its high oxygen mobility is particularly appropriate as a support for catalysts used in oxidation reactions. Indeed, this oxide, besides acting as a dispersing carrier, would itself participate to the oxidation reaction through the Mars-van Krevelen mechanism [26,27]. Furthermore, as compared to other rare-earth oxides with a propensity towards a stronger metal-support interaction, ceria does not decorate the metal particles, avoiding the negative consequence of burying the catalyst active sites [28]. As a way to increase the oxygen mobility, making the oxidation process more efficient, $\mathrm{CeO}_{2}$ is doped with trivalent $\mathrm{Me}^{3+}$ rare earth ions leading to a defective structure, through oxygen vacancies formation [29]. Just recently, our team reported the positive effect of $\mathrm{Y}^{3+}$ modified ceria on the supported gold catalysts for the $\mathrm{CO}$ preferential oxidation reaction [30]. According to the literature, the oxygen ion conductivity of Y-doped ceria is a function of the dopant concentration. Large amount of yttrium (above 10-15 at. \%) leads to a decrease in the oxygen mobility related with an increasing ordering of oxygen vacancies [31-33]. A recent investigation of the influence of the ceria Y-doping on the catalytic properties of supported gold catalysts in $\mathrm{CBO}$ reaction, established a beneficial effect of $1 \mathrm{wt}$. $\% \mathrm{Y}_{2} \mathrm{O}_{3}$ added to ceria by impregnation method [34]. In the present study, as a continuation of the previous work, the combination of a bimetallic $\mathrm{Pd}-\mathrm{Au}$ system with the Y-doped ceria as support was explored. The specific atomic ratio between gold and palladium was selected for comparison purposes, based on previous investigation on supported $\mathrm{Au}$ (3 wt. \%) catalyst [10-12]. In order to understand the reciprocal effect of each catalyst component, the catalytic behaviors in $\mathrm{CBO}$ reaction of $\mathrm{Au}, \mathrm{Pd}$ and $\mathrm{Pd}-\mathrm{Au}$ catalysts supported on $\mathrm{CeO}_{2}$ and on $\mathrm{Y}$-doped $\mathrm{CeO}_{2}$ were compared. Furthermore, two different procedures for yttrium addition, aiming to modify just the surface or the bulk, were exploited. From the fundamental point of view, the study focused on the structure- $\mathrm{CBO}$ reactivity relationship. For practical application, the study aimed lowering the temperature for complete combustion of benzene, in order to reduce the operating cost of air pollution abatement processes.

\section{Results and Discussion}

\subsection{Catalytic Activity Measurements}

The conversion of benzene was always towards total oxidation. No intermediate products of partial oxidation were detected. The catalytic results in terms of benzene conversion as a function of the reaction temperature are given in Figure 1. The notation of the various samples is clarified in the Experimental section.

For clarity's sake, each plot of Section A compares the conversion obtained by the three different catalyst formulations (the 2 monometallic and 1 bimetallic catalysts) over the same support. Each panel of Section B compares the conversion obtained by the same catalyst formulation over the three different supports. 

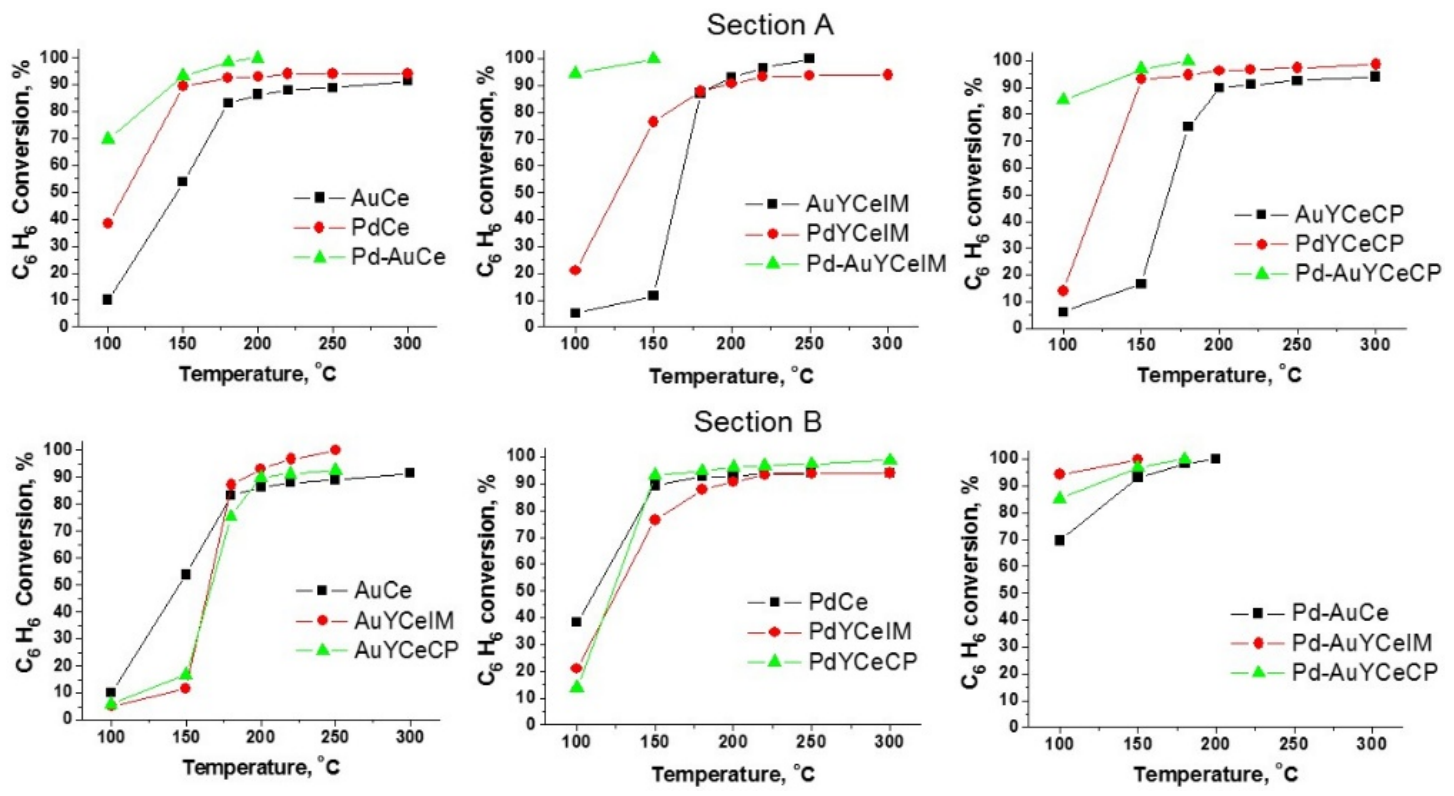

Figure 1. Benzene conversion as function of temperature (A) for the different catalyst formulations over the same supports; (B) for the same formulation over the three different supports.

As clearly seen in Section A of Figure 1, regardless the support composition, and in analogy with similar catalysts supported on Fe-doped ceria, at temperature below $200{ }^{\circ} \mathrm{C}$, the conversion over Pd catalysts, despite the lower Pd loading as compared to Au loading, was always higher than over Au catalysts [25]. The superiority of the palladium catalysts as compared to gold catalysts was also reported in toluene oxidation performed with $\mathrm{Au}$ and $\mathrm{Pd}$ catalysts supported on mesoporous $\mathrm{TiO}_{2}$ and on $\mathrm{CeO}_{2}-\mathrm{Y}_{2} \mathrm{O}_{3}$ wash coated cordierite honeycomb [35-37]. The bimetallic catalysts exhibited a noticeable improvement, with a significant lowering of the maximum conversion temperature.

The effect of the support is more evident in the plots of Section B. On the monometallic gold catalysts, the presence of $\mathrm{Y}$ inhibited the activity in the temperature interval up to $175^{\circ} \mathrm{C}$. A slight improvement of the activity above $175^{\circ} \mathrm{C}\left(100 \%\right.$ benzene conversion at $\left.250{ }^{\circ} \mathrm{C}\right)$ was observed for the Y-promoted gold catalysts, to a large extent for the catalyst over the IM prepared support as compared to the one over the co-precipitation (CP) support ( $85 \%$ benzene conversion). The better performance in the case of the IM support was related to an additional contribution to the oxidation activity, arising from the gold on $\mathrm{Y}_{2} \mathrm{O}_{3}$ entity formed during impregnation, as it was earlier reported [30]. Guzman and Corma have indeed described that nanocrystalline $\mathrm{Y}_{2} \mathrm{O}_{3}$ stabilizes active species of gold, increasing the $\mathrm{CO}$ oxidation activity of the gold catalyst [38]. Likewise, in the present study, the separate $\mathrm{Y}_{2} \mathrm{O}_{3}$ phase, being in close contact with gold, could act as a co-catalyst and contribute to the increase in the activity. The Pd-containing samples exhibited similar conversion regardless the different supports. As for the gold case, yttrium doping had a slight detrimental effect at the lower temperatures up to $150{ }^{\circ} \mathrm{C}$.

Among the bimetallic catalysts, yttrium doping produced an evident positive effect on their activity. The Pd-AuYCeIM exhibited the best CBO performance with $94 \%$ benzene conversion at $100{ }^{\circ} \mathrm{C}$ and full conversion at $150{ }^{\circ} \mathrm{C}$, a significantly lower temperature as compared to what has been reported so far [25]. Moreover, as shown in Figure S1, the Pd-AuYCeIM catalyst tested for $72 \mathrm{~h}$ at $150^{\circ} \mathrm{C}$ maintained a stable activity. 


\subsection{Sample Characterization}

The specific surface areas $\left(\mathrm{S}_{\mathrm{BET}}\right)$ and pores data are given in Table 1 along with the structural parameters obtained from XRD and HRTEM.

Table 1. Specific surface area $\left(\mathrm{S}_{\mathrm{BET}}\right)$, mean pore diameter $(\mathrm{d})$ and pore volume $(\mathrm{v})$, as estimated by physisorption measurements; lattice constant of ceria (a) and average size of ceria crystallites ( $\mathrm{D}_{\mathrm{XRD}}$ ) estimated by X-ray powder diffraction (XRD); gold particle sizes (D) estimated by High resolution transmission electron microscopy (HRTEM) / high-angle annular dark-field (HAADF).

\begin{tabular}{|c|c|c|c|c|c|c|}
\hline \multirow{2}{*}{ Catalyst } & \multirow{2}{*}{$\mathrm{S}_{\mathrm{BET}}\left(\mathrm{m}^{2} / \mathrm{g}\right)$} & $\mathrm{d}(\mathrm{nm})$ & $\mathrm{v}\left(\mathrm{cm}^{3} / \mathrm{g}\right)$ & \multirow{2}{*}{$\begin{array}{c}\mathrm{a}_{\mathrm{XRD}} \\
\left(\mathrm{CeO}_{2}\right)(\mathrm{nm})\end{array}$} & \multirow{2}{*}{$\begin{array}{c}\mathrm{D}_{\mathrm{XRD}} \\
\left(\mathrm{CeO}_{2}\right)(\mathrm{nm})\end{array}$} & \multirow{2}{*}{$\begin{array}{c}\text { D HRTEM } \\
(\mathrm{Au})(\mathrm{nm})\end{array}$} \\
\hline & & \multicolumn{2}{|c|}{ Desorption Branch } & & & \\
\hline $\mathrm{AuCe}$ & 102.4 & 1.7 & 0.15 & $0.5412(7)$ & 6.1 & 2.1 \\
\hline $\mathrm{PdCe}$ & 101.9 & 1.7 & 0.15 & $0.5419(4)$ & 8.4 & \\
\hline $\mathrm{Pd}-\mathrm{AuCe}$ & 101.0 & 1.7 & 0.15 & $0.5419(4)$ & 7.6 & $2.2 / 2.6^{*}$ \\
\hline AuYCeIM & 103.0 & 1.6 & 0.16 & $0.5410(5)$ & 6.9 & 2.6 \\
\hline PdYCeIM & 105.0 & 1.6 & 0.15 & $0.5417(6)$ & 9.0 & \\
\hline Pd-AuYCeIM & 105.5 & 1.6 & 0.16 & $0.5412(4)$ & 8.4 & $2.4 / 4.9^{* *}$ \\
\hline $\mathrm{AuYCeCP}$ & 90.0 & 3.8 & 0.12 & $0.5411(4)$ & 7.5 & 3.2 \\
\hline PdYCeCP & 89.6 & 3.7 & 0.11 & $0.5416(5)$ & 7.9 & \\
\hline Pd-AuYCeCP & 90.0 & 3.8 & 0.12 & $0.5414(11)$ & 8.8 & $2.6 / 2.6^{*}$ \\
\hline
\end{tabular}

$\mathrm{S}_{\mathrm{BET}}$ values were around $100 \pm 10 \mathrm{~m}^{2} / \mathrm{g}$. No substantial differences existed between mono and bimetallic catalysts. The specific surface areas of the catalysts in the case of the CP prepared support were consistently lower as compared to the case of the impregnated (IM) support. The comparison of pore size distribution and pore volume pointed out to a slight different porosity driven by the preparation method. Similar pore diameters $(\sim 1.6 \mathrm{~nm})$ and similar pore volumes $\left(\sim 0.15 \mathrm{~cm}^{3} / \mathrm{g}\right)$ were obtained for the bare and the $\mathrm{Y}$ impregnated $\mathrm{CeO}_{2}$ supported catalysts. Larger pore diameters, centered at $\sim 3.7 \mathrm{~nm}$, and smaller pore volume, around $0.11-0.12 \mathrm{~cm}^{3} / \mathrm{g}$, characterized the CP samples.

The structure of the catalysts was investigated by XRD diffraction and by HRTEM analyses. As shown in Figure 2 for all the palladium containing samples, the X-ray diffraction patterns presented reflections typical of the fluorite structure of $\mathrm{CeO}_{2}$ with no evidence of any yttrium or palladium related phases. The close values of the ionic radius of $\mathrm{Ce}^{4+}(0.97 \AA)$ and the $\mathrm{Y}^{3+}$ dopant $(1.02 \AA)$ should have favored solid solution formation. However, as shown in Table 1, the dopant concentration was too low to induce significant differences in the XRD derived ceria cell parameter. Moreover, the absence of any palladium related peaks suggested a high dispersion of this element. The bimetallic samples exhibited weak $\mathrm{Au}$ (111) peak, typical of a pure metal gold phase centered at $2 \theta=38.2^{\circ}$ [30]. This result confirmed the presence of separate Au aggregates. As reported in literature, particle structures formed by a gold core with a thin palladium shell could also be in accord with such XRD patterns [39].

In Table 1 the gold particle sizes obtained from HRTEM analyses of the fresh samples are listed. HRTEM sizes of selected samples after the CBO reactions are also given. With respect to palladium, both XRD and HRTEM techniques failed to yield reliable information. Indeed, the similarity of the lattice distances of $\mathrm{PdO}$ and those of $\mathrm{CeO}_{2}$, made very difficult to distinguish unambiguously by HRTEM the ceria crystals from the PdO ones [25]. The measurements of the interplanar distances in selected HRTEM images of the AuYCeIM catalyst substantiated the presence of $\mathrm{Y}_{2} \mathrm{O}_{3}$ crystals (not detectable by XRD) [30]. 


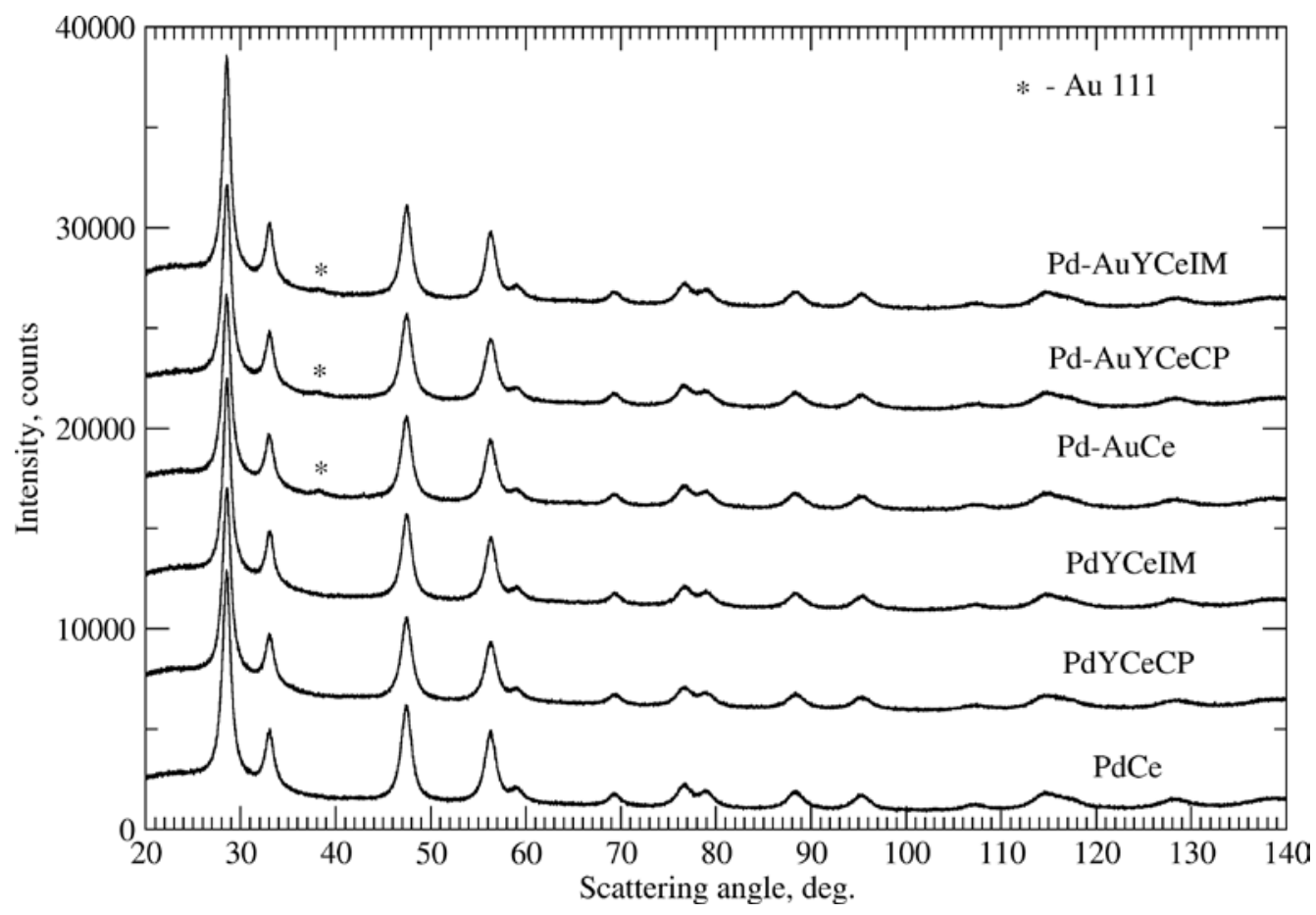

Figure 2. XRD patterns of the Pd containing catalysts.

In order to obtain information on oxygen mobility, sample reducibility was evaluated by means of TPR measurements [34,40]. It is widely accepted that the reduction of ceria proceeds in two steps: reduction of surface layers at around $500{ }^{\circ} \mathrm{C}$ and bulk reduction at higher temperatures (over $800^{\circ} \mathrm{C}$ ) [41]. Doping ceria with $\mathrm{Me}^{3+}$ with ionic radius $>0.8 \AA$ produces oxygen vacancies compensating for the excess of negative charge [42]. Therefore, by doping ceria with $\mathrm{Y}^{3+}$ (ionic radius $1.02 \AA$ ), oxygen vacancies will be formed, thus changing the oxygen mobility and, accordingly, the ceria redox properties. The IM method of the support preparation caused mainly surface modification, that is, the vacancies were predominantly located at the surface. Differently, the insertion of $\mathrm{Y}^{3+}$ by $\mathrm{CP}$ lead to oxygen vacancies in the whole volume, in other words, relatively fewer surface defects were expected as compared to supports prepared by IM. These observations were confirmed by the comparison of the TPR profiles of ceria surface reduction of the $\mathrm{CP}$ and IM supports as well as of bare $\mathrm{CeO}_{2}$ given in Figure 3. The TPR profile of the CP support did not differ substantially from that of bare ceria, but its maximum was located at slightly lower temperatures. The support prepared by IM exhibited higher reducibility characterised by the lower temperature feature at $410{ }^{\circ} \mathrm{C}$ of a more complex TPR peak.

The TPR profiles of the catalysts are shown in Figure 4. In accord with previous observation, the presence of gold induced a significant lowering of the surface ceria reduction temperature $[43,44]$. Indeed the low temperature peak assigned to the reduction of the surface layers of ceria (the contribution of positively charged gold particles reduction is negligible) was complete at $200{ }^{\circ} \mathrm{C}$, differently from the original supports giving rise to low temperature peaks extending in the $300-550{ }^{\circ} \mathrm{C}$ range (Figure 3). The TPR profiles of the Au catalysts on Y-doped ceria did not differ significantly. The profiles presented a shoulder at a higher temperature corresponding to the AuCe surface reduction, and a low temperature feature-attributable to the $Y$ - promoted surface ceria reduction [34]. The lack of correlation between the catalyst reducibility and the catalytic activity suggested that the slight increase in reducibility induced by yttrium was not able to compensate for the small increase in the gold and ceria particle sizes (Table 1). Consequently, the net result was a detrimental effect on the CBO conversion as shown in Figure 1. 


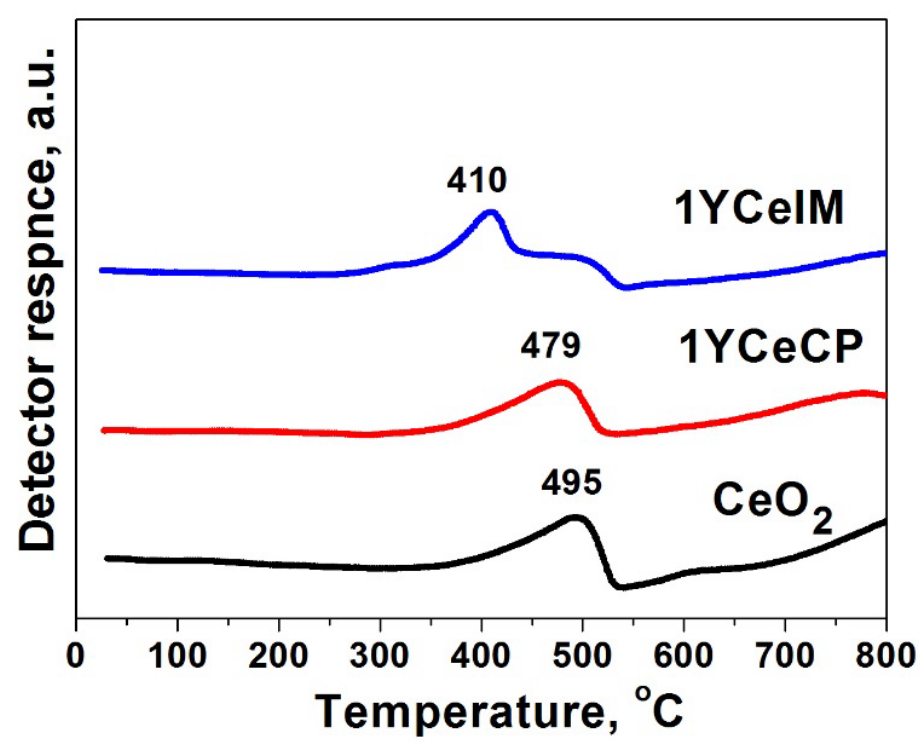

Figure 3. Temperature programmed reduction (TPR) profiles of the initial supports.

The TPR profiles of the Pd-containing catalysts (Figure 4B,C) were characterized by sharp peaks shifted to a lower temperature as compared to the gold samples, especially in the case of bimetallic composition $\left(\mathrm{T}_{\max }\right.$ at $20-37^{\circ} \mathrm{C}$ ). Corroborated by other techniques such as XPS, the peaks were assigned to the reduction of both, oxidized palladium and surface ceria oxide. The increased surface ceria reducibility upon $\mathrm{Pd}$ loading would in fact explain the higher $\mathrm{CBO}$ activity of $\mathrm{Pd}$ as compared to the Au catalysts (Figure $1 \mathrm{~A}$ ). The broad TPR peaks in the temperature range $300-500{ }^{\circ} \mathrm{C}$ (outside the range of interest for the $\mathrm{CBO}$ reaction), registered only for the Pd-containing samples, were attributed to the reduction of deeper ceria layers activated by palladium. The theoretical values of hydrogen consumption (HC) for ceria surface reduction were, according to literature, $0.49-0.58 \mathrm{mmol} \mathrm{g}^{-1}$ for pure ceria and $0.49-0.57 \mathrm{mmol} \mathrm{g}^{-1}$ for ceria doped with $1 \mathrm{wt}$. \% $\mathrm{Y}_{2} \mathrm{O}_{3}[45,46]$.

As seen in Table 2, the HC experimental values were in good agreement with the theoretical ones. The values up to $250{ }^{\circ} \mathrm{C}$ of around $0.7 \mathrm{mmol} \mathrm{g}^{-1}$ for the metal containing catalysts on both Y-doped supports (excluding the HC for Pd-AuYCeIM) were higher as compared to those for AuCe or PdCe. Considering that the hydrogen consumption required to reduce palladium according to the reaction $\mathrm{PdO}+\mathrm{H}_{2} \rightarrow \mathrm{Pd}^{0}$ is $0.08 \mathrm{mmol} \mathrm{g}^{-1}$, the results confirmed the Y-enhanced surface oxygen mobility of the modified ceria. As evidenced by the low temperature shift of the TPR maxima the combination of $\mathrm{Pd}$ and $\mathrm{Au}$ caused substantial increase in the surface ceria reducibility.

Table 2. Experimental hydrogen consumption (HC) during TPR of the studied catalysts.

\begin{tabular}{ccc}
\hline \multirow{2}{*}{ Catalyst } & \multicolumn{2}{c}{ HC $\left(\mathbf{m m o l ~ g}^{\mathbf{- 1}}\right)$} \\
\cline { 2 - 3 } & $\mathbf{C P}$ & $\mathbf{I M}$ \\
\hline AuCe & $0.5^{\mathrm{a}, \mathrm{b}}$ & $0.5^{\mathrm{a}, \mathrm{b}}$ \\
AuYCe & $0.6^{\mathrm{a}, \mathrm{b}}$ & $0.6^{\mathrm{a}, \mathrm{b}}$ \\
PdCe & $0.6^{\mathrm{a}} / 1.0^{\mathrm{b}}$ & $0.6^{\mathrm{a}} / 1.0^{\mathrm{b}}$ \\
PdYCe & $0.7^{\mathrm{a}} / 1.4^{\mathrm{b}}$ & $0.7^{\mathrm{a}} / 1.2^{\mathrm{b}}$ \\
Pd-AuCe & $0.6^{\mathrm{a}} / 1.2^{\mathrm{b}}$ & $0.6^{\mathrm{a}} / 1.2^{\mathrm{b}}$ \\
Pd-AuYCe & $0.7^{\mathrm{a}} / 1.1^{\mathrm{b}}$ & $0.5^{\mathrm{a}} / 1.1^{\mathrm{b}}$ \\
\hline${ }^{\mathrm{a}} \mathrm{HC}$ during the TPR to $250^{\circ} \mathrm{C}^{\mathrm{b}} \mathrm{HC}$ during the TPR to $800^{\circ} \mathrm{C}$
\end{tabular}



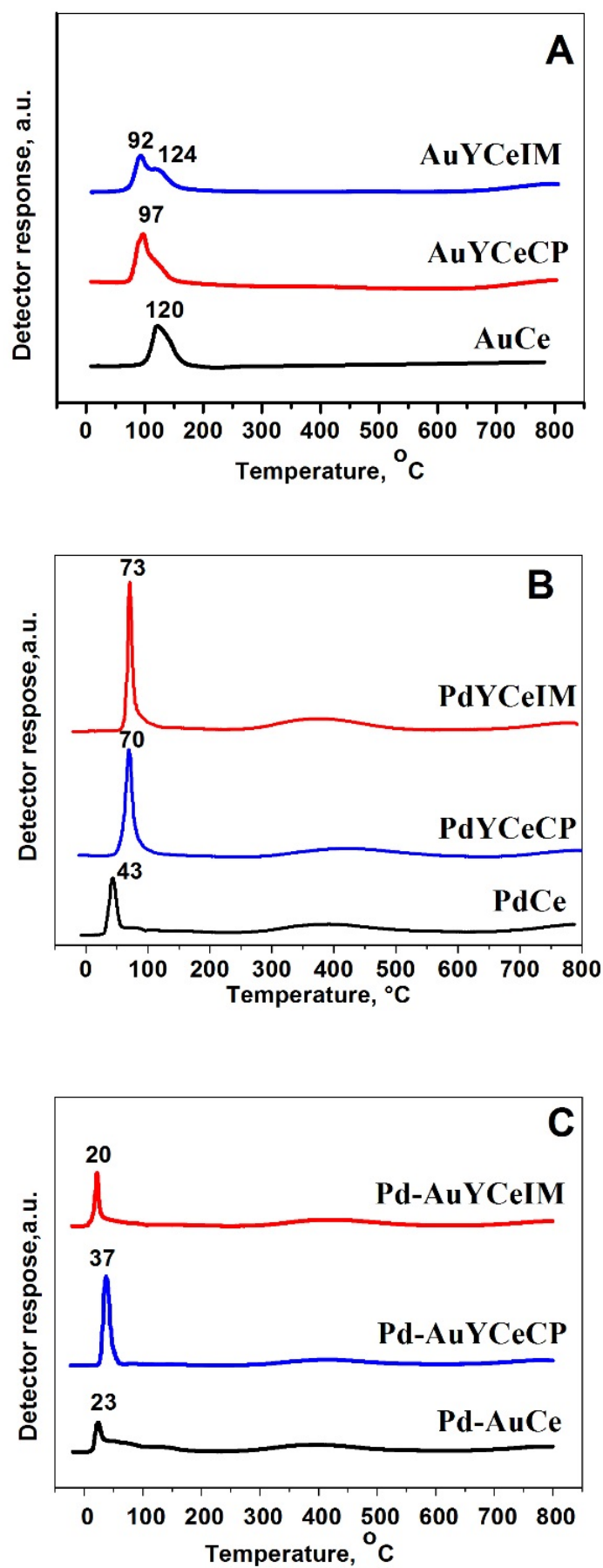

Figure 4. TPR profiles of monometallic Au (A), monometallic Pd (B) and bimetallic Pd-Au catalysts (C) on ceria and Y-doped ceria supports.

A correlation between the TPR results and the catalytic activity was particularly evident in the benzene conversion values registered at $100{ }^{\circ} \mathrm{C}$. Indeed, $70 \%$ conversion was obtained with $\mathrm{Pd}-\mathrm{AuCe}$ as compared to $30 \%$ conversion with $\mathrm{Pd}-\mathrm{Ce}$ and to even lower conversion with $\mathrm{Au}-\mathrm{Ce}$. Concerning the yttrium doped samples, $80 \%$ and $90 \%$ conversions with $\mathrm{Pd}-\mathrm{AuYCeCP}$ and $\mathrm{Pd}-\mathrm{AuYCeIM}$, respectively, were obtained (see Figure 1B).

In order to explain the lower hydrogen consumption observed with the bimetallic sample over the IM support, an experiment that aimed to simulate the sample conditions at the beginning of the TPR analyses was performed. Specifically, Pd 3d photoelectron spectra of both catalysts were collected 
after hydrogen treatment at room temperature. As observed in Figure 5 , beside the $\operatorname{Pd} 3 d_{5 / 2}$ oxide component at $337.7 \mathrm{eV}$, a metallic component at $335.4 \mathrm{eV}$, characterized by a slight asymmetry on the high energy side, was present in both sample spectra. The metallic component with respect to the oxide component was more intense in the case of the PdAuYCeIM as compared to the PdAuYCeCP sample. Then, it was reasonable to conclude that, in spite of the lower HC, the sample Pd-AuYCeIM was in fact easier to reduce at room temperature and accordingly it exhibited higher $\mathrm{CBO}$ conversion. Similar observation was reported for $\mathrm{Pd}-\mathrm{Au}$ catalysts supported over $\mathrm{Fe}-$ modified $\mathrm{CeO}_{2}$ [25].

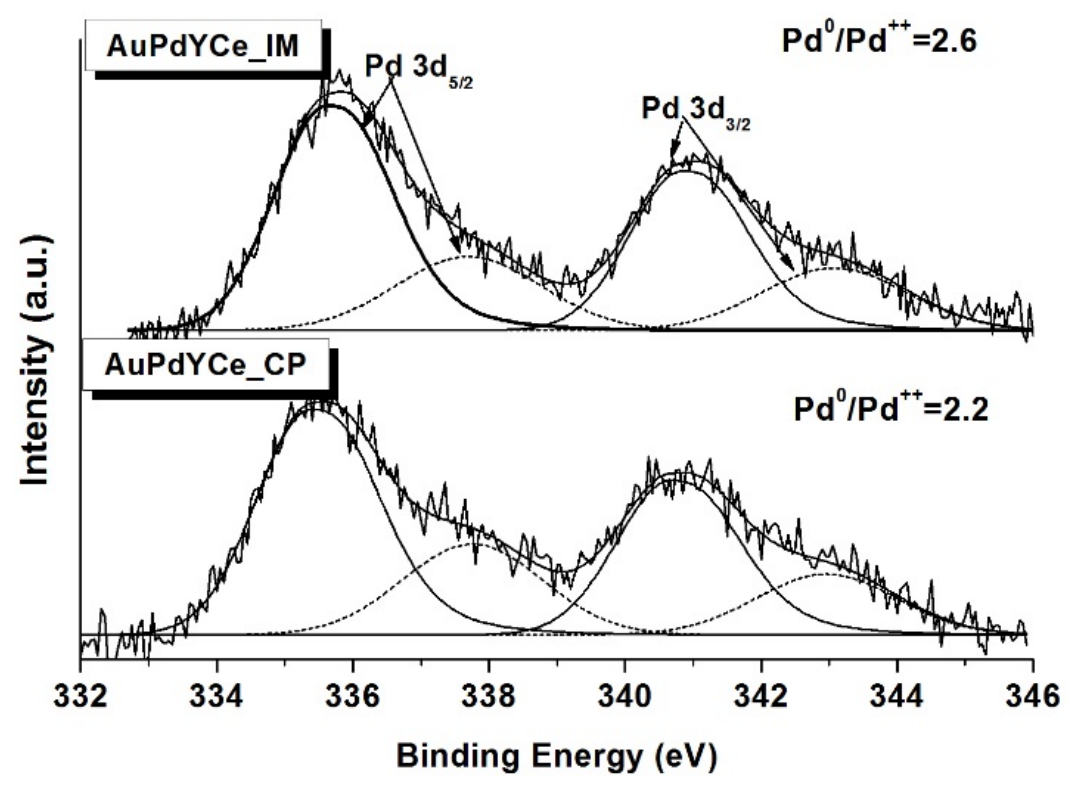

Figure 5. Pd 3d XP spectra of Pd-AuYCeIM and Pd-AuYCeCP catalysts after hydrogen treatment at room temperature.

The surface variation in terms of chemical composition and oxidation states, was investigated by XPS analyses of fresh (calcined) and spent samples. The results were summarized in Table 3. The Au $4 \mathrm{f}_{7 / 2}$ binding energies (BE) of the fresh monometallic gold catalysts were typical of metallic $\mathrm{Au}^{0}$ [47]. The presence of yttrium induced a slight increase in the $\mathrm{BE}$ indicative of positively charged $\mathrm{Au}^{\delta+}$, to a large extent in the AuYCeCP catalyst. The monometallic palladium catalysts were characterized by $\mathrm{Pd} 3 \mathrm{~d}_{5 / 2} \mathrm{BE}$ of $337.1 \pm 0.1 \mathrm{eV}$ typical of $\mathrm{Pd}^{2+}$. A significant binding energy shift to $337.6 \pm 0.2 \mathrm{eV}$ occurred in the case of the bimetallic $\mathrm{Pd}-\mathrm{Au}$ samples [16]. As already observed, concerning the $\mathrm{Ce}$ oxidation state, all the samples contained $\mathrm{Ce}^{4+}$ with a minor percentage of $\mathrm{Ce}^{3+}$ ions, some of which due to X-ray beam induced reduction during the XPS analyses [30]. The O 1s region contained two contributions, one due to lattice oxygen with $\mathrm{BE}$ of $529.4 \pm 0.3 \mathrm{eV}$, the other to hydroxyl species with $\mathrm{BE}$ of $531.8 \pm 0.4 \mathrm{eV}$ [48]. The binding energy of $\mathrm{Y} 3 \mathrm{~d}_{5 / 2}$ at $157.6 \pm 0.2 \mathrm{eV}$ was typical of $\mathrm{Y}^{3+}$. In some of the samples, a second $Y 3 d_{5 / 2}$ component at lower energy (about $153.3 \pm 0.3 \mathrm{eV}$ ) was registered [49]. Such component was attributed to partially reduced yttrium $\mathrm{Y}^{(3-\delta)+}$, indicative of a closer interaction with the noble metal. With respect to the surface atomic ratios as determined by XPS, the Au catalysts presented a gold enriched surface (the nominal $\mathrm{Au} / \mathrm{Ce}=0.03$ ), as expected from an impregnation procedure. In the presence of palladium, the $\mathrm{Au} / \mathrm{Ce}$ ratio decreased, due to the sequential palladium deposition over the gold catalysts, hiding part of the gold. In all the samples, surface enrichment of palladium was observed, indeed the $\mathrm{Pd} / \mathrm{Ce}$ atomic ratios were always much larger than the nominal ones (0.016). The tendency of a higher Pd/Ce ratio for the case of Y-containing ceria as compared to bare ceria was indicative of an improved Pd dispersion caused by the presence of $\mathrm{Y}$ or of a Pd surface segregation driven by yttrium. The $\mathrm{Y} / \mathrm{Ce}$ atomic ratios were also larger than the analytical one $(0.016)$ confirming $\mathrm{Y}^{3+}$ segregation at the ceria surface. 
Table 3. X-ray photoelectron spectroscopy (XPS) data in terms of binding energies and atomic ratios.

\begin{tabular}{|c|c|c|c|c|c|c|c|}
\hline Sample & $\mathrm{Au} 4 \mathrm{f}_{7 / 2} \mathrm{eV}$ & $P d 3 d_{5 / 2} e V$ & $Y 3 d_{5 / 2} e V$ & $\mathrm{O} 1 \mathrm{~s} \mathrm{eV}$ & $\begin{array}{c}\mathrm{Pd} / \mathrm{Ce} \\
(0.016) *\end{array}$ & $\begin{array}{l}\mathrm{Au} / \mathrm{Ce} \\
(0.03) \text { * }\end{array}$ & $\begin{array}{c}\mathrm{Y} / \mathrm{Ce} \\
(0.016)\end{array}$ \\
\hline $\mathrm{AuCe}$ & 84.3 & & & $\begin{array}{l}529.3(57 \%) \\
531.6(43 \%)\end{array}$ & & 0.06 & \\
\hline $\mathrm{AuYCeCP}$ & 85.1 & & $\begin{array}{l}157.7(66 \%) \\
153.8(34 \%)\end{array}$ & $\begin{array}{l}529.5(79 \%) \\
532.0(21 \%)\end{array}$ & & 0.06 & 0.09 \\
\hline AuYCeIM & 84.5 & & 157.4 & $\begin{array}{l}529.4(77 \%) \\
532.0(23 \%)\end{array}$ & & 0.06 & 0.15 \\
\hline PdCe & & 337.1 & & $\begin{array}{l}529.6(80 \%) \\
531.4(20 \%)\end{array}$ & 0.14 & & \\
\hline PdYCeCP & & 337.2 & $\begin{array}{l}157.5(57 \%) \\
153.4(43 \%)\end{array}$ & $\begin{array}{l}529.6(73 \%) \\
532.2(27 \%)\end{array}$ & 0.49 & & 0.25 \\
\hline PdYCeIM & & 337.1 & $\begin{array}{l}157.7(81 \%) \\
153.2(19 \%)\end{array}$ & $\begin{array}{l}529.4(78 \%) \\
531.7(22 \%)\end{array}$ & 0.36 & & 0.21 \\
\hline $\mathrm{Pd}-\mathrm{AuCe}$ & 84.5 & 337.6 & & $\begin{array}{l}529.5(76 \%) \\
531.8(24 \%)\end{array}$ & 0.25 & 0.03 & \\
\hline $\begin{array}{c}\mathrm{Pd}-\mathrm{AuCe} \\
\text { spent in CBO }\end{array}$ & 84.2 & $\begin{array}{l}337.7(88 \%) \\
335.3(12 \%)\end{array}$ & & $\begin{array}{l}529.5(76 \%) \\
531.6(24 \%)\end{array}$ & 0.15 & 0.02 & \\
\hline Pd-AuYCeCP & 84.8 & 337.5 & $\begin{array}{l}157.4(70 \%) \\
153.2(30 \%)\end{array}$ & $\begin{array}{l}529.4(82 \%) \\
531.5(18 \%)\end{array}$ & 0.32 & 0.04 & 0.04 \\
\hline $\begin{array}{l}\text { Pd-AuYCeCP } \\
\text { spent in CBO }\end{array}$ & 84.6 & $\begin{array}{l}337.8(66 \%) \\
336.3(34 \%)\end{array}$ & 157.6 & $\begin{array}{l}529.7(74 \%) \\
531.9(26 \%)\end{array}$ & 0.19 & 0.02 & 0.09 \\
\hline Pd-AuYCeIM & 84.8 & 337.4 & $\begin{array}{l}157.6(63 \%) \\
153.7(37 \%)\end{array}$ & $\begin{array}{l}529.3(64 \%) \\
531.4(36 \%)\end{array}$ & 0.33 & 0.04 & 0.07 \\
\hline $\begin{array}{l}\text { Pd-AuYCeIM } \\
\text { spent in CBO }\end{array}$ & 84.5 & $\begin{array}{l}337.7(52 \%) \\
336.4(48 \%)\end{array}$ & 158.0 & $\begin{array}{l}529.6(74 \%) \\
531.8(26 \%)\end{array}$ & 0.16 & 0.02 & 0.09 \\
\hline
\end{tabular}

The modification of the Pd $3 \mathrm{~d}$ and $\mathrm{Y} 3 \mathrm{~d}$ spectra of $\mathrm{Pd}-\mathrm{Au}$ samples upon catalytic reaction were shown in Figures 6 and 7. The corresponding XPS results were also listed in Table 3. These spent samples exhibited a small but still significant decrease of the $\mathrm{Au} 4 \mathrm{f}_{7 / 2}$ binding energy and a splitting of the Pd 3d spectrum into two components, one attributed to oxidized palladium species and the other to a more reduced palladium. The BE typical of metallic Pd is generally around $335 \mathrm{eV}$ [15]. The larger value obtained in the present case could be attributed to a close interaction of the support oxides with palladium. Modification of the $Y 3 d$ spectra were not so sharp except for a slight increase in the $Y 3 d$ binding energy upon CBO. Overall, these XPS results suggested the involvement of palladium oxide and, to a minor extent, of gold in the catalytic oxidation of benzene with the consequent reduction of the two noble metal species.

The relative amount of reduced palladium was enhanced by the presence of yttrium. The slight decrease in $\mathrm{Pd} / \mathrm{Ce}$ and $\mathrm{Au} / \mathrm{Ce}$ atomic ratios, observed upon benzene oxidation reaction, could be attributed to a partial sintering of the metal crystallites, as confirmed for the gold particles by the HRTEM data given in Table 1. Moreover, the increased $\mathrm{Y} / \mathrm{Ce}$ atomic ratio upon $\mathrm{CBO}$ reaction was in accord with a reaction driven surface segregation of yttrium. 


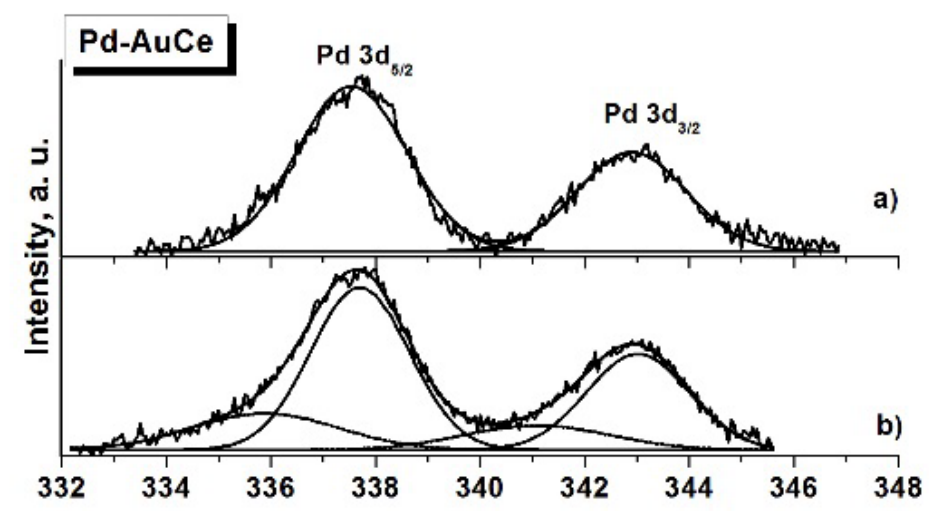

Binding Energy (eV)

(A)

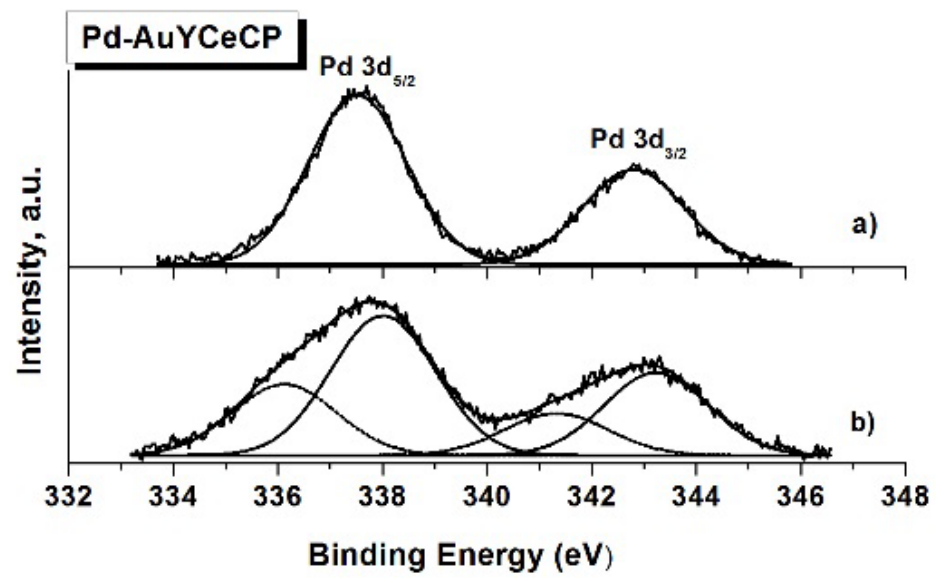

(B)

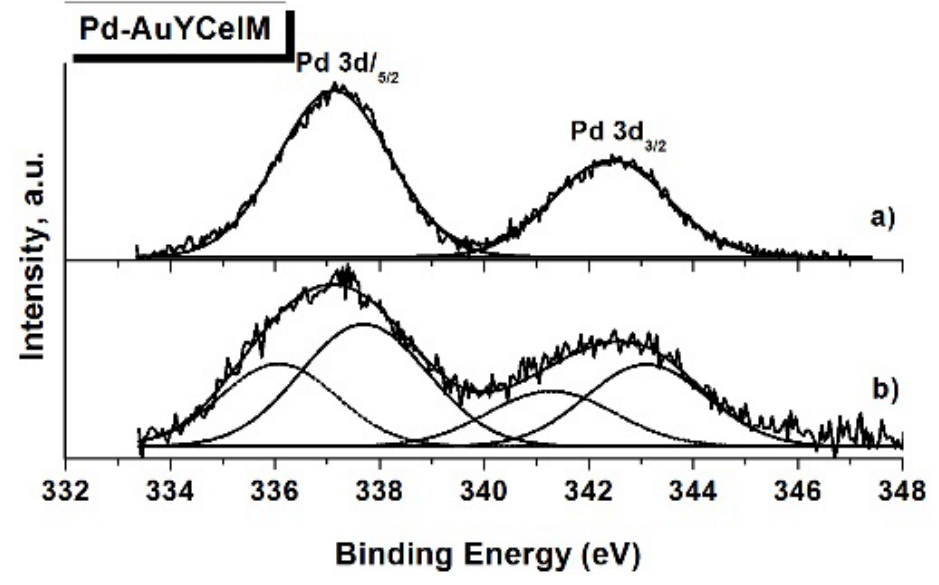

(C)

Figure 6. Pd $3 d$ XP spectra of (A) Pd-AuCe catalyst as: (a) fresh and (b) after CBO; (B) Pd-AuYCeCP catalyst as: (a) fresh and (b) after CBO; (C) Pd-AuYCeIM catalyst as: (a) fresh and (b) after CBO. 


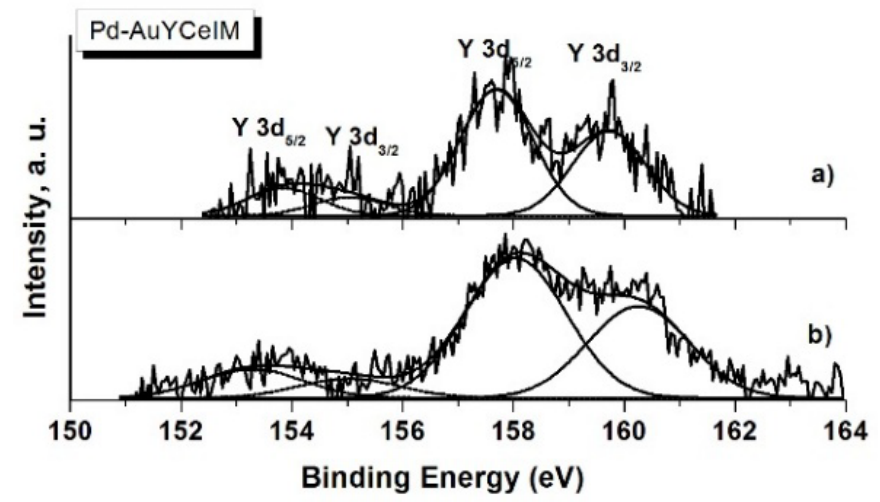

(A)

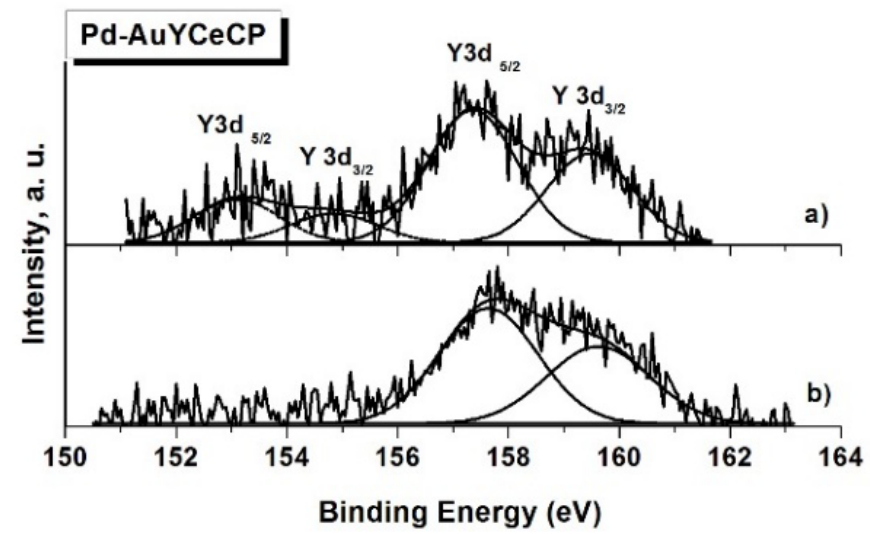

(B)

Figure 7. Y $3 d$ XP spectra of: (A) Pd-AuYCeIM catalyst as: (a) fresh and (b) after CBO; (B) Pd-AuYCeCP catalyst as: (a) fresh and (b) after CBO.

According to the literature, VOCs total oxidation over gold supported on reducible oxides takes place through Mars-van Krevelen redox mechanism with the participation of active oxygen supplied by the surface of the oxide support ([4] and references therein). Concerning the catalytic oxidation of organic molecules with Pd-containing catalysts, many studies supported the Langmuir-Hinshelwood mechanism. Accordingly, a reaction between adsorbed oxygen and adsorbed hydrocarbon molecules on the metal sites would occur. However, in the presence of reducible supports, the possibility of an oxidative-reductive Mars-van Krevelen mechanism cannot be excluded [50]. The activation of oxygen via adsorption by direct Pd participation (Langmuir-Hinshelwood model) or the Pd enhanced active oxygen provision by the support (Mars-van Krevelen model) depends on the support reducibility. In case of hardly reducible supports, during the oxidation process via the Langmuir-Hinshelwood mechanism, the noble metals would function at their reduced states. Hence, $\mathrm{O}_{2}$ undergoes dissociation over the metal sites and VOCs species are adsorbed over the metal sites without dissociation [50]. In a very recent review, F. Roudesly et al. [51] summarized various cases of metal-promoted C-H activation. They observed that the majority of the $\mathrm{Pd}$-catalyzed $\mathrm{C}-\mathrm{H}$ activation processes takes place at $\mathrm{Pd}^{2+}$ because the electron poor transition metals in high oxidation states, such as $\mathrm{Pd}^{2+}$, may react with the electrons of the substrate via electrophilic activation. The $\pi$-electron rich aromatic molecule would be attracted by the vacant $\mathrm{Pd}^{2+}$ sites. Then, by electron transfer, the reaction would proceed through formation of $\mathrm{Pd}^{0}$, which the oxidizing system brings back to its initial $\mathrm{Pd}^{2+}$ oxidation state [52]. Swinging between metallic $\mathrm{Pd}$ and $\mathrm{PdO}$ phases was reported for methane combustion over $\mathrm{Pd}-\mathrm{LaMnO}_{3}$ catalysts [53]. In the case of benzene oxidation with palladium supported on a zeolite, a not-reducible oxide, the authors suggested that the redox center $\left(\mathrm{Pd}^{0}\right)$ would be oxidized by the $\mathrm{O}_{2}$ stream [54]. 
In the present study, the modification of the oxidation state of gold and palladium upon CBO, observed by XPS, was in favor of Mars-van Krevelen redox mechanism. The electron rich aromatic molecule tends to interact with the initially positively charged palladium resulting in $\mathrm{Pd}^{2+}$ reduction to $\mathrm{Pd}^{0}$ and in the organic molecule oxidation. For the most active bimetallic system, the XPS data clearly showed that after the reaction, $\mathrm{Pd}^{2+}$ species transformed into $\mathrm{Pd}^{0}$, meaning that an electron donation occurred from benzene molecule to palladium. In the presence of the reducible support, following the Mars-van Krevelen mechanism, the lattice oxygen from the $\mathrm{CeO}_{2}$ would oxidize the metallic $\mathrm{Pd}^{0}$ and the redox process will continue. The sample reducibility, strictly related to the oxygen mobility, crucial for the Mars-van Krevelen mechanism, followed the catalytic trend: Pd-AuYCeIM > Pd-AuYCeCP $>$ Pd-AuCe.

In conclusion, the improved $\mathrm{CBO}$ activity of the bimetallic formulation with respect to the monometallic palladium, particularly at lower temperature $\left(<150^{\circ} \mathrm{C}\right)$, was attributable to a combination of the electronic effects played by the two noble metals. Indeed, according to TPR, gold and palladium, acting in synergy, contributed to the enhancement of the support reducibility. Moreover, the presence of gold, as suggested by the photoelectron Pd $3 \mathrm{~d}$ binding energies, lowers the surface electronic charge at the Pd sites, therefore favoring the mechanism described above for the activation of benzene. The role of a light $\mathrm{Y}$-doping consisted in a further increase of the surface ceria reducibility, more evident in the case of the impregnated (IM) support.

\section{Experimental}

\subsection{Sample Preparation}

Three series of monometallic Au (3 wt. \%) and Pd (1 wt. \%) and bimetallic Pd (1 wt. \%)-Au ( $3 \mathrm{wt}$. \%) catalysts supported over bare ceria and over ceria, modified by $\mathrm{Y}$ using wet impregnation (IM) or co-precipitation $(\mathrm{CP})$ were synthesized. The amount of yttrium corresponded to $1 \mathrm{wt}$. $\% \mathrm{Y}_{2} \mathrm{O}_{3}$.

The preparation of ceria was carried out by precipitation of $0.5 \mathrm{M}$ solution of $\mathrm{Ce}\left(\mathrm{NO}_{3}\right)_{3} \cdot 6 \mathrm{H}_{2} \mathrm{O}$ with $1 \mathrm{M}$ solution of $\mathrm{K}_{2} \mathrm{CO}_{3}$ at temperature $=60^{\circ} \mathrm{C}$ and constant $\mathrm{pH}=9$. The precursor was aged at the same temperature for $1 \mathrm{~h}$. Then, the gel was filtered and carefully washed until no $\mathrm{NO}_{3}{ }^{-}$ions were detected. Thermal treatment included drying in vacuum at $80{ }^{\circ} \mathrm{C}$ and calcination in air at $400{ }^{\circ} \mathrm{C}$ for $2 \mathrm{~h}$. The impregnation of ceria with aqueous solution containing the calculated amount of $\mathrm{Y}\left(\mathrm{NO}_{3}\right)_{3} \cdot 6 \mathrm{H}_{2} \mathrm{O}$ was carried out by stirring at room temperature for $4 \mathrm{~h}$. Then, the suspension was evaporated at $70{ }^{\circ} \mathrm{C}$. The resulting $\mathrm{Y}$ impregnated ceria was calcined in air at $400{ }^{\circ} \mathrm{C}$ for $2 \mathrm{~h}$. Using the $\mathrm{CP}$ method, mixed solutions of $\mathrm{Ce}\left(\mathrm{NO}_{3}\right)_{3} \cdot 6 \mathrm{H}_{2} \mathrm{O}$ and $\mathrm{Y}\left(\mathrm{NO}_{3}\right)_{3} \cdot 6 \mathrm{H}_{2} \mathrm{O}$ at a desired ratio were co-precipitated with a solution of $\mathrm{K}_{2} \mathrm{CO}_{3}$ at constant $\mathrm{pH}=9$ and temperature $=60^{\circ} \mathrm{C}$. The precipitates were aged at the same temperature for $1 \mathrm{~h}$, filtered and washed until removal of $\mathrm{NO}_{3}{ }^{-}$ions. The following thermal treatments were the same as described above. Prior to deposition of the metals, the supports were dispersed in water and activated in an ultrasound disintegrator.

Gold was added by deposition-precipitation method from $\mathrm{HAuCl}_{4} \cdot 3 \mathrm{H}_{2} \mathrm{O}$ and $\mathrm{K}_{2} \mathrm{CO}_{3}$ precursors. The precipitation of $0.06 \mathrm{M}$ solution of $\mathrm{HAuCl}_{4} \cdot 3 \mathrm{H}_{2} \mathrm{O}$ was carried out at constant $\mathrm{pH}=7$, temperature $=60^{\circ} \mathrm{C}$, stirring speed $=250 \mathrm{rpm}$, reactant feed flow rates $=0.15 \mathrm{~L} \mathrm{~h}^{-1}$. The precursors were filtered and washed. Then, the solids were dried under vacuum and calcined in air at $400{ }^{\circ} \mathrm{C}$ for $2 \mathrm{~h}$. The gold catalysts were denoted as AuCe, AuYCeIM and AuYCeCP.

For preparation of Pd-containing samples $\mathrm{Pd}\left(\mathrm{NO}_{3}\right)_{2} \cdot \mathrm{xH}_{2} \mathrm{O}$ was used following the preparation method and calcination procedure described above for the gold catalysts. These samples were denoted as PdCe, PdYCeIM, and PdYCeCP.

The sequential deposition-precipitation was carried out for synthesis of bimetallic $\mathrm{Pd}-\mathrm{Au}$ catalysts. $\mathrm{Pd}$ was deposited on the preliminary prepared and calcined Au/Y-doped ceria. Calcination in air at $400{ }^{\circ} \mathrm{C}$ for $2 \mathrm{~h}$ was carried out after Pd deposition. The samples were denoted as Pd-AuCe, $\mathrm{Pd}-\mathrm{AuYCeIM}$ and Pd-AuYCeCP. 


\subsection{Sample Characterization}

The BET surface area $\left(\mathrm{S}_{\mathrm{BET}}\right)$ and pore size distribution of the samples were evaluated performing nitrogen adsorption/desorption experiments with a Carlo Erba Sorptomat 1900 instrument (Milan, Italy). Prior to the measurements, the samples were outgassed at $200{ }^{\circ} \mathrm{C}$ for $1 \mathrm{~h}$ under vacuum. The fully computerized analysis of the nitrogen adsorption isotherm at $-196{ }^{\circ} \mathrm{C}$ allowed estimation of the specific surface areas of the samples in the standard pressure range $0.05-0.3 \mathrm{P} / \mathrm{P}_{0}$. Mean pore diameter and pore volume were calculated by applying the Barrett, Joyner, and Halenda (BJH) method to the desorption isotherm in the range $0.1-0.99 \mathrm{P} / \mathrm{P}_{0}$. The uncertainty on the estimated values is $\pm 10 \%$.

The actual gold and palladium loadings for each catalyst was $3( \pm 0.05) \mathrm{wt}$. \% and $1( \pm 0.05) \mathrm{wt}$. \% as measured by Atomic Absorption spectroscopy using Varian Vista MPX apparatus.

X-ray powder diffraction (XRD) measurements were performed using a D5000 diffractometer (Bruker AXS, Karlsruhe, Germany)), with Cu sealed tube operating at $40 \mathrm{kV}$ and $40 \mathrm{~mA}$. The setup employed Bragg-Brentano focusing geometry with $1 \mathrm{deg}$. beam divergence and LynxEye strip detector. The data were analyzed using PeakFit program (Jandel Scientific, Corte Madera, CA, USA) as well as Fityk (Copyright 2001-2014 Marcin Wojdar, Warszawa, Poland) fitting XRD profiles to $\mathrm{K}_{\alpha} 1$ 1,2 doublets having PEARSON VII analytical form. The $\mathrm{CeO}_{2}$ phase was analyzed on the basis of 14 well measured reflections and Williamson-Hall plot [55] and the average crystal size was calculated. The crystal size of gold particles was estimated on the basis of the strongest (111) reflection as the only one detectable. The procedure is given in more details in Ref. [33].

High resolution transmission electron microscopy (HRTEM) analyses of the calcined catalysts were performed in a JEM 2010 FasTem analytical microscope (Jeol, Tokyo, Japan) equipped with a Z-contrast annular detector that allows obtaining high-angle annular dark-field scanning (HAADF) images. The average size of the gold particles and the histograms of the particle sizes were established from the measurement of 900 to 1200 particles obtained by HAADF observations. The size limit for the detection of gold particles on $\mathrm{TiO}_{2}$ was about $0.5 \mathrm{~nm}$. The average particle diameter $\mathrm{d}_{\mathrm{s}}$ was calculated using the following formula: $d_{s}=\sum n_{i} d_{i} / \sum n_{i}$ where $n_{i}$ is the number of particles of diameter $d_{i}$.

The X-ray photoelectron spectroscopy (XPS) analyses were performed with a VG Microtech ESCA 3000 Multilab (VG Scientific, Sussex, UK), equipped with a dual Mg/Al anode following the same experimental procedure as before [16]. The constant charging of the samples was removed by referencing all the energies to the $\mathrm{C} 1 \mathrm{~s}$ set at $285.1 \mathrm{eV}$, arising from the adventitious carbon. Analyses of the peaks were performed with the software provided by VG, based on non-linear least squares fitting program with Lorentzian and Gaussian component curves after background subtraction according to Shirley and Sherwood [56].

The temperature programmed reduction (TPR) measurements were carried out by means of an apparatus described elsewhere [8]. A cooling trap $\left(-40^{\circ} \mathrm{C}\right)$ for removing water formed during reduction was mounted in the gas line prior to the thermal conductivity detector. A hydrogen-argon mixture $\left(10 \% \mathrm{H}_{2}\right)$, dried over a molecular sieve $5 \mathrm{~A}\left(-40{ }^{\circ} \mathrm{C}\right)$, was used to reduce the samples at a flow rate of $24 \mathrm{~mL} \mathrm{~min}{ }^{-1}$. The temperature increased by $15{ }^{\circ} \mathrm{C} \mathrm{min}^{-1}$. The amount of sample used was $0.05 \mathrm{~g}$, based on a criterion proposed by Monti and Baiker [57]. Hydrogen consumption during the reduction process was calculated using preliminary calibration of the thermal conductivity detector, performed by reducing different amounts of $\mathrm{NiO}$ to $\mathrm{Ni}^{0}$ (NiO-'analytical grade', calcined at $800{ }^{\circ} \mathrm{C}$ for $2 \mathrm{~h}$ to avoid the presence of non-stoichiometric oxygen). For XPS investigation purposes, a supplemental experiment of mild reduction for $30 \mathrm{~min}$ at room temperature was performed with $\mathrm{Pd}-\mathrm{AuYCeIM}$ and Pd-AuYCeCP catalysts.

\subsection{Catalytic Activity Measurements in $C B O$}

The catalytic tests at atmospheric pressure, in the temperature range $100-300{ }^{\circ} \mathrm{C}$, were performed in a continuous flow fixed bed microreactor connected to a gas chromatograph (Hewlett Packard 5890 series II, Wimington, Germany) equipped with a flame ionization detector, using capillary HP Plot $Q$ column. The following conditions were chosen: catalyst bed volume of $0.5 \mathrm{~cm}^{3}$ (particle size 
$0.25-0.50 \mathrm{~mm}$ ), inlet benzene concentration $42 \mathrm{~g} \mathrm{~m}^{-3}$ in air, space velocity $4000 \mathrm{~h}^{-1}$. The catalysts were activated "in situ" flowing pure air for $1 \mathrm{~h}$ at $350^{\circ} \mathrm{C}$ [34].

\section{Conclusions}

Two series of $\mathrm{Pd}, \mathrm{Au}$, and bimetallic $\mathrm{Pd}-\mathrm{Au}$ catalysts supported on 1 wt. $\% \mathrm{Y}_{2} \mathrm{O}_{3}$ doped $\mathrm{CeO}_{2}$ were tested in the catalytic combustion of benzene. The Y-doping procedure, co-precipitation or impregnation, by affecting the structural and morphological properties of the catalysts played a small but still significant role. The substantial lowering of the ceria surface reduction temperature in the presence of $\mathrm{Pd}$ correlated with the higher $\mathrm{CBO}$ activity of monometallic $\mathrm{Pd}$ catalysts as compared to $\mathrm{Au}$ catalysts. Moreover, according to the TPR analyses, the two noble metals synergistically enhanced the support oxygen mobility, reflected in an improved benzene conversion of the bimetallic catalysts with respect to the monometallic ones. The addition of yttrium, particularly when added by impregnation, contributed to a further increase in the support reducibility. The modification of the oxidation state, as detected by XPS, of the two noble metals after the CBO reaction confirmed the redox character of the studied reaction, with the aromatic molecule interacting with the electron depleted $\mathrm{Pd}^{2+}$ species and the lattice oxygen contributing to the re-oxidation of palladium.

The bimetallic catalyst over the impregnated support exhibited the best performance, quite promising for practical application. Indeed, the Pd-AuYCeIM sample attained total benzene combustion at the low temperature of $150{ }^{\circ} \mathrm{C}$, maintaining stable activity over a period of more than $70 \mathrm{~h}$.

Supplementary Materials: The following are available online at http:/ /www.mdpi.com/2073-4344/8/7/10. $3390 /$ catal8070283/s1, Figure S1. Stability test of Pd-AuYCeIM catalyst performed for $72 \mathrm{~h}$ at $150^{\circ} \mathrm{C}$.

Author Contributions: A.M.V., T.T., and L.I. have written the manuscript. P.P. has prepared the samples and she performed the catalytic tests. G.P. has made TPR experiments, L.F.L. performed morphology analyses, A.M.V. performed XPS analyses. R.Z. performed HRTEM analyses. Z.K. performed XRD analyses.

Funding: This research received no external funding.

Acknowledgments: P.P.: Y.K. and T.T. gratefully acknowledge financial support by the Bulgarian Science Fund (Project DFNI T 02/4). R.Z. acknowledges the financial support granted by PDCPN-CONACYT-1216 and the technical support provided by V. Maturano. The authors acknowledge also a support by the COST Action CM1104.

Conflicts of Interest: The authors declare no conflict of interest.

\section{References}

1. Kamal, M.S.; Razzak, S.A.; Hossain, M.M. Catalytic oxidation of volatile organic compounds (VOCs)—A review. Atmos. Environ. 2016, 140, 117-134. [CrossRef]

2. Liotta, L.F. Catalytic oxidation of volatile organic compounds on supported noble metals. Appl. Catal. B Environ. 2010, 100, 403-412. [CrossRef]

3. Solsona, B.; Pérez-Cabero, M.; Vázquez, I.; Dejoz, A.; García, T.; Álvarez-Rodríguez, J.; El-Haskouri, J.; Beltrán, D.; Amorós, P. Total oxidation of VOCs on Au nanoparticles anchored on Co doped mesoporous UVM-7 silica. Chem. Eng. J. 2012, 187, 391-400. [CrossRef]

4. Scirè, S.; Liotta, L.F. Supported gold catalysts for the total oxidation of volatile organic compounds. Appl. Catal. B Environ. 2012, 125, 222-246. [CrossRef]

5. Tidahy, H.L.; Hosseini, M.; Siffert, S.; Cousin, R.; Lamojnier, J.-F.; Aboukiais, A.; Su, B.-L.; Giraudon, J.-M.; Leclerq, G. Nanosrutuctured macro-mesoporous zirconia impregnated by noble metal for catalytic total oxidation of toluene. Catal. Today 2008, 137, 335-339. [CrossRef]

6. Kim, S.C.; Shim, W.G. Properties and performance of Pd based catalysts for catalytic oxidation of volatile organic compounds. Appl. Catal. B Environ. 2009, 92, 429-436. [CrossRef]

7. Centi, G. Supported palladium catalysts in environmental catalytic technologies for gaseous emissions. J. Mol. Catal. A Chem. 2001, 173, 287-312. [CrossRef] 
8. Andreeva, D.; Tabakova, T.; Ilieva, L.; Naydenov, A.; Mehanjiev, D.; Abrashev, M.V. Nanosize gold catalysts promoted by vanadium oxide supported on titania and zirconia for complete benzene oxidation. Appl. Catal. A Gen. 2001, 209, 291-300. [CrossRef]

9. Andreeva, D.; Nedyalkova, R.; Ilieva, L.; Abrashev, M.V. Gold-vanadia catalysts supported on ceria-alumina for complete benzene oxidation. Appl. Catal. B Environ. 2004, 52, 157-165. [CrossRef]

10. Andreeva, D.; Petrova, P.; Ilieva, L.; Abrashev, M.V. Gold supported on ceria and ceria-alumina promoted by molybdena for complete benzene oxidation. Appl. Catal. B Environ. 2006, 67, 237-245. [CrossRef]

11. Andreeva, D.; Petrova, P.; Ilieva, L.; Sobczak, J.W.; Abrashev, M.V. Design of new gold catalysts supported on mechanochemically activated ceria-alumina, promoted by molybdena for complete bezene oxidation. Appl. Catal. B Environ. 2008, 77, 364-372. [CrossRef]

12. Ilieva, L.; Petrova, P.; Tabakova, T.; Zanella, R.; Abrashev, M.V.; Sobczak, J.W.; Lisowski, W.; Kaszkur, Z.; Andreeva, D. Relationship between structural properties and activity in complete benzene oxidation over $\mathrm{Au} / \mathrm{CeO}_{2}-\mathrm{CoO}_{\mathrm{x}}$ catalysts. Catal. Today 2012, 187, 30-38. [CrossRef]

13. Pretzer, L.A.; Song, H.J.; Fang, Y.L.; Zhao, Z.; Guo, N.; Wu, T.; Arslan, I.; Miller, J.T.; Wong, M.S. Hydrodechlorination catalysis of Pd-on-Au nanoparticles varies with particle size. J. Catal. 2013, 298, 206-217. [CrossRef]

14. Lopez-Sanchez, J.A.; Dimitratos, N.; Glanville, N.; Kesavan, L.; Hammond, C.; Edwards, J.K.; Carley, A.F.; Kiely, C.J.; Hutchings, G.J. Reactivity studies of Au-Pd supported nanoparticles for catalytic applications. Appl. Catal. A Gen. 2011, 391, 400-406. [CrossRef]

15. Venezia, A.M.; La Parola, V.; Pawelec, B.; Fierro, J. Hydrogenation of aromatics over Au-Pd/SiO $\mathrm{S}_{2}-\mathrm{Al}_{2} \mathrm{O}_{3}$ catalysts; support acidity effect. Appl. Catal. A Gen. 2004, 264, 43-51. [CrossRef]

16. Venezia, A.M.; Murania, R.; Pantaleo, G.; Deganello, G. Pd and PdAu on mesoporous silica for methane oxidation: Effect of $\mathrm{SO}_{2}$. J. Catal. 2007, 251, 94-102. [CrossRef]

17. Bonarowska, M.; Malinowski, A.; Juszczyk, W.; Karpinski, Z. Hydrodechlorination of $\mathrm{CCl}_{2} \mathrm{~F}_{2}(\mathrm{CFC}-12)$ over silica-supported palladium-gold catalysts. Appl. Catal. B Environ. 2001, 30, 187-193. [CrossRef]

18. Alshammari, A.; Kalevaru, V.N.; Martin, A. Bimetallic catalysts containing gold and palladium for environmentally important reactions. Catalysts 2016, 6, 97. [CrossRef]

19. Shao, S.S.; Wang, H.; Zhang, M.; Ma, D.D.; Lee, S.T. The mutual promotional effect of Au-Pd bimetallic nanoparticles on silicon nanowires: A study of preparation and catalytic activity. Appl. Phys. Lett. 2008, 93, 243110. [CrossRef]

20. Lee, D.S.; Che, Y.W. The mutual promotional effect of $\mathrm{Au}-\mathrm{Pd} / \mathrm{CeO}_{2}$ bimetallic catalysts on destruction of toluene. J. Taiwan Inst. Chem. Eng. 2013, 44, 40-44. [CrossRef]

21. Hosseini, M.; Siffert, S.; Cousin, R.; Aboukaïs, A.; Hadj-Sadok, Z.; Su, B.-L. Total oxidation of VOCs on $\mathrm{Pd}$ and/or Au supported on $\mathrm{TiO}_{2} / \mathrm{ZrO}_{2}$ followed by "operando" DRIFT. C. R. Chim. 2009, 12, 654-659. [CrossRef]

22. Takatani, H.; Kago, H.; Kobayashi, Y.; Hori, F.; Oshima, R. Properties of Au-Pd nanoparticles prepared by sono-chemical technique. Trans. Mater. Res. Soc. Jpn. 2003, 28, 871-874.

23. Enache, D.I.; Edwards, J.K.; Landon, P.; Solsona-Espriu, B.; Carley, A.F.; Herzing, A.A.; Watanabe, M.; Kiely, C.J.; Knight, D.W.; Hutchings, G.J. Solvent-Free oxidation of primary alcohols aldhehides using au-Pd/ $\mathrm{TiO}_{2}$ catalysts. Science 2006, 311, 362-365. [CrossRef] [PubMed]

24. Hosseini, M.; Barakat, T.; Cousin, R.; Aboukaïs, A.; Su, B.-L.; De Weireld, G.; Siffert, S. Catalytic performance of core-shell and alloy Pd-Au nanoparticles for total oxidation of VOC: The effect of metal deposition. Appl. Catal. B Environ. 2012, 111-112, 218-224. [CrossRef]

25. Tabakova, T.; Ilieva, L.; Petrova, P.; Venezia, A.M.; Avdeev, G.; Zanella, R.; Karakirova, Y. Complete benzene oxidation over mono and bimetallic Au-Pd catalysts supported on Fe-modified ceria. Chem. Eng. J. 2015, 260, 133-141. [CrossRef]

26. Centeno, M.A.; Paulis, M.; Montes, M.; Odriozola, J.A. Catalytic combustion of volatile organic compounds on $\mathrm{Au} / \mathrm{CeO}_{2} / \mathrm{Al}_{2} \mathrm{O}_{3}$ and $\mathrm{Au} / \mathrm{Al}_{2} \mathrm{O}_{3}$ catalysts. Appl. Catal. A Gen. 2002, 234, 65-78. [CrossRef]

27. Jiang, X.; Hua, J.; Deng, H.; Wu, Z. Influence of pre-added $\mathrm{NaOH}$ on the microstructure of $\mathrm{Au}-\mathrm{CeO}_{2}$ catalyst and its activity for benzene oxidation. J. Mol. Catal. A Chem. 2014, 383-384, 188-193. [CrossRef]

28. Colussi, S.; Trovarelli, A.; Cristiani, C.; Lietti, L.; Groppi, G. The influence of ceria and other rare earth promoters on palladium-based methane combustion catalysts. Catal. Today 2012, 180, 124-130. [CrossRef] 
29. Nilsson, J.O.; Leetmaa, M.; Vekilova, O.Y.; Simak, S.I.; Skorodumova, N.V. Oxygen diffusion in ceria doped with rare-earth elements. Phys. Chem. Phys. 2017, 19, 13723-13730. [CrossRef] [PubMed]

30. Ilieva, L.; Petrova, P.; Pantaleo, G.; Zanella, R.; Liotta, L.F.; Georgiev, V.; Boghosian, S.; Kaszkur, Z.; Sobczak, J.W.; Lisowski, W.; et al. Gold catalysts supported on Y-modified ceria for CO free hydrogen production via PROX. Appl. Catal. B Environ. 2016, 188, 154-168. [CrossRef]

31. Ou, D.R.; Mori, T.; Ye, F.; Takahashi, M.; Zou, J.; Drennan, J. Microstructures and electrolytic properties of yttrium-doped ceria electrolytes: Dopant concentration and grain size dependences. Acta Mater. 2006, 54, 3737-3746. [CrossRef]

32. Burbano, M.; Norberg, S.T.; Hull, S.; Eriksson, S.G.; Marrocchelli, D.; Madden, P.A.; Watson, G.W. Oxygen vacancy ordering and the conductivity maximum in $\mathrm{Y}_{2} \mathrm{O}_{3}$-doped $\mathrm{CeO}_{2}$. Chem. Mater. 2012, 24, 222-229. [CrossRef]

33. Yan, P.F.; Mori, T.; Suzuki, A.; Wu, Y.Y.; Auchterlonie, G.J.; Zou, J.; Drennan, J. Grain boundary's conductivity in heavily yttrium doped ceria. Solid State Ion. 2012, 222, 31-37. [CrossRef]

34. Ilieva, L.; Petrova, P.; Liotta, L.F.; Sobczak, J.W.; Lisowski, W.; Kaszkur, Z.; Munteanu, G.; Tabakova, T. Gold catalysts on Y-doped ceria supports for complete benzene oxidation. Catalysts 2016, 6, 99. [CrossRef]

35. Ousmane, M.; Liotta, L.F.; Di Carlo, G.; Pantaleo, G.; Venezia, A.M.; Deganello, G.; Retailleau, L.; Boreave, A.; Giroir-Fendler, A. Supported Au catalysts for low-temperature abatment of propene and toluene, as model VOC: Support effect. Appl. Catal. B Environ. 2011, 101, 629-637. [CrossRef]

36. Barakat, T.; Idakiev, V.; Cousin, R.; Shao, G.-S.; Yuan, Z.-Y.; Tabakova, T.; Siffert, S. Total oxidation of toluene over noble metal based Ce, Fe, and Ni doped Titanium oxide. Appl. Catal. B Environ. 2014, 146, 138-146. [CrossRef]

37. Luo, M.F.; He, M.; Xie, Y.L.; Fang, P.; Jin, L.Y. Toluene oxidation on Pd catalysts supported by $\mathrm{CeO}_{2}-\mathrm{Y}_{2} \mathrm{O}_{3}$ washcoat cordierite honeycomb. Appl. Catal. B Environ. 2007, 69, 213-218. [CrossRef]

38. Guzman, J.; Corma, A. Nanocrystalline and mesostructured $\mathrm{Y}_{2} \mathrm{O}_{3}$ as supports for gold catalysts. Chem. Commun. 2005, 6, 743-745. [CrossRef] [PubMed]

39. Kaszkur, Z.; Juszczyk, W.; Łomot, D. Self diffusion in nanocrystalline alloys. Phys. Chem. Chem. Phys. 2015, 17, 28250-28255. [CrossRef] [PubMed]

40. Konsolakis, M.; Carabineiro, S.A.; Tavares, P.B.; Figueiredo, J.L. Redox properties and VOC oxidation activity of $\mathrm{Cu}$ catalysts supported on $\mathrm{Ce}_{1-x} \mathrm{Sm}_{x} \mathrm{O}_{\delta}$ mixed oxides. J. Hazard. Mater. 2013, 261, 512-521. [CrossRef] [PubMed]

41. Yao, H.C.; Yao, Y.F.Y. Ceria in automotive exhaust catalysts: I. Oxygen storage. J. Catal. 1984, 86, $254-265$. [CrossRef]

42. Trovarelli, A. Catalytic properties of ceria and $\mathrm{CeO}_{2}$-containing materials. Catal. Rev. 1996, 38, 439-520. [CrossRef]

43. Fu, Q.; Weber, A.; Flytzani-Stephanopoulos, M. Nanostructured Au-CeO $\mathrm{C}_{2}$ catalysts for low-temperature water-gas shift. Catal. Lett. 2001, 77, 87-95. [CrossRef]

44. Andreeva, D.; Idakiev, V.; Tabakova, T.; Ilieva, L.; Falaras, P.; Bourlinos, A.; Travlos, A. Low-temperature water-gas shift reaction over $\mathrm{Au} / \mathrm{CeO}_{2}$ catalysts. Catal. Today 2002, 72, 51-57. [CrossRef]

45. Sanchez, M.G.; Gazquez, J.L. Oxygen vacancy model in strong metal-support interaction. J. Catal. 1987, 104, 120-135. [CrossRef]

46. Laachir, A.; Perrichon, V.; Bardi, A.; Lamotte, J.; Catherine, E.; Lavalley, J.C.; El Faallah, J.; Hilaire, L.; Le Normand, F.; Quemere, E.; et al. Reduction of $\mathrm{CeO}_{2}$ by hydrogen. Magnetic susceptibility and Fourier-transform infrared, ultraviolet and X-ray photoelectron spectroscopy measurements. J. Chem. Soc. Faraday Trans. 1991, 87, 1601-1609. [CrossRef]

47. Casaletto, M.P.; Longo, A.; Martorana, A.; Prestianni, A.; Venezia, A.M. XPS stydy of supported gold catalysts: The role of $\mathrm{Au}^{0}$ and $\mathrm{Au}^{+\delta}$ species as active sites. Surf. Interface Anal. 2006, 38, 215-218. [CrossRef]

48. Monte, M.; Munuera, G.; Costa, D.; Conesa, J.C.; Martínez-Arias, A. Near-ambient XPS characterization of interfacial copper species in ceria-supported copper catalysts. Phys. Chem. Chem. Phys. 2015, 17, 29995-30004. [CrossRef] [PubMed]

49. He, X.; Yang, H. A novel strategy to the synthesis of $\mathrm{Na}_{3} \mathrm{YSi}_{2} \mathrm{O}_{7}$ from natural palygorskite. Appl. Clay Sci. 2014, 101, 339-344. [CrossRef]

50. Zhang, Z.; Jiang, Z.; Shangguan, W. Low-temperature catalysis for VOCs removal in technology and application: A state-of-the-art review. Catal. Today 2016, 264, 270-278. [CrossRef] 
51. Roudesly, F.; Oble, J.; Poli, G. Metal-catalyzed CH activation/functionalization: The fundamentals. J. Mol. Catal. A Chem. 2017, 426, 275-296. [CrossRef]

52. Moritani, I.; Fujiwara, Y. Aromatic substitution of styrene-palladium chloride complex. Tetrahedron Lett. 1967, 8, 1119-1122. [CrossRef]

53. Cimino, S.; Casaletto, M.P.; Lisi, L.; Russo, G. Pd-LaMnO 3 as dual site catalysts for methane combustion. Appl. Catal. A Gen. 2007, 327, 238-246. [CrossRef]

54. Hea, C.; Li, J.; Li, P.; Cheng, J.; Hao, Z.; Xu, Z.-P. Comprehensive investigation of Pd/ZSM-5/MCM-48 composite catalysts with enhanced activity and stability for benzene oxidation. Appl. Catal. B Environ. 2010, 96, 466-475. [CrossRef]

55. Mote, V.D.; Purushotham, Y.; Dole, B.N. Williamson-Hall analysis in estimation of lattice strain in nanometer-sized ZnO particles. J. Theor. Appl. Phys. 2012, 6, 6. [CrossRef]

56. Sherwood, P.M.A. Practical Surface Analysis; Briggs, D., Seah, M.P., Eds.; Wiley: New York, NY, USA, 1990; pp. 555-585.

57. Monti, D.A.M.; Baiker, A. Temperature-programmed reduction. Parametric sensitivity and estimation of kinetic parameters. J. Catal. 1983, 83, 323-335. [CrossRef]

(C) 2018 by the authors. Licensee MDPI, Basel, Switzerland. This article is an open access article distributed under the terms and conditions of the Creative Commons Attribution (CC BY) license (http:/ / creativecommons.org/licenses/by/4.0/). 